\title{
The Benefits (and Costs) of Foresight and Hindsight in Macro Policy Formulation
}

\author{
Nigel Stapledon ${ }^{1}$
}

\section{Abstract}

This paper looks at the difficulties for fiscal and monetary policy posed by the inherent uncertainty of the economic outlook. It contrasts the excessive optimism of policymakers in the approach to the 1989-91 recession with the excessive pessimism of the outlook in Australia in 2008.

In the May 2009 Budget, it was stated that the magnitude and speed of transmission of the global recession means that a recession in Australia has become inevitable' ${ }^{2}$ In precise terms, GDP was forecast to contract for at least three quarters by a cumulative $1 \frac{1}{4}$ per cent, thereby meeting the technical definition of recession. The unemployment rate was projected to rise from its lows of about 4.1 per cent (March quarter 2008), by about $4 \frac{1}{2}$ percentage points (ppts), to a peak of somewhere over $8 \frac{1}{2}$ per cent in 2010. And but for fiscal and monetary policy stimulus, the Government forecast that GDP would have contracted $4 \frac{1}{4}$ per cent and the peak in unemployment would have been somewhere over 10 per cent: in short, a more severe recession than experienced in 1989-91 when GDP contracted 1.6 per cent and unemployment rose by 4 ppts from a low of 6.7 per cent (December quarter 1989) to a peak two years later of 10.8 per cent. ${ }^{3}$

While it is probably unfair to judge these forecasts with hindsight, this is the only objective criterion we have. In the Treasury's defence one may refer to similar forecasts from the consensus of private-sector forecasters (Gruen 2010). On the other hand, that is rather circuitous, given the propensity of privatesector forecasts to mimic the Treasury forecasts - most forecasters operate on the premise that being wrong is $\mathrm{OK}$ as long as you are in good company. What is critical here is not the forecast error, but the 'certainty' attached to it, a point to which I return later.

$1 \quad$ School of Economics, UNSW; nigel.stapledon@unsw.edu.au

2 Australian Government 2009a, Table 1: domestic economy forecasts.

3 Sources: ABS 5206.0 Table 2 for GDP and ABS 6202.0 Table 2 for seasonally adjusted unemployment rate.

Estimates of unemployment rate are averages for the quarter. 
Past recessions tend to be a guiding influence on thinking about causes and responses to subsequent recessions or downswings in the business cycle. As the most significant recession in post-1945 Australia, the 1989-91 recession cast a significant shadow over the 2008-09 policy response to the GFC-related downswing. Most of the attention appears to have been focused on the role of fiscal and monetary policy in the 1989-91 recession, with alleged policy failure said by some to have been a significant factor in the depth and duration of that recession.

It entirely reasonable that policy shaped in some way the depth and duration of that recession, but its role is probably overstated. As noted by Gruen and Stevens (2003: 53), the 'distinguishing feature of the late 1980s boom and subsequent slump was the role of asset prices, accommodated by rapid credit expansion by newly liberated financial intermediaries.' They cited Macfarlane (1989, 1990), who had contended that lax lending standards by banks, coupled with the interaction of tax and inflation (i.e. nominal interest tax deductibility and leveraging on asset-price inflation), helped explain the apparent imperviousness of investors (for a time at least) to high interest rates in the 1980s. The asset bubble in equities burst in 1987 but with minimal effect on the real economy (Simon 2003: 35).

It was the subsequent asset-price bubble in property, particularly in commercial property, which had a much more significant effect on the real economy. In the office property market in the period 1986-89, prices rose at 20-30 per cent per annum (Simon 2003: Figure 14). ${ }^{4}$ Crucially, the high returns led to an upswing in construction activity which, to judge against history, can be crudely measured in the high proportion of activity accounted for by construction activity (Figure 1 below and Simon 2003. When the bubble burst, Australia was left with surplus office space, which then took about a decade to work through and office building prices contracted about 60 per cent in real terms (Simon 2003: Figure 14). From the peak of activity (September quarter 1989) to the trough (September quarter 1993) the decline in non-residential construction expenditure was 42 per cent, ${ }^{6}$ taking the share of construction from 5.3 per cent to 2.6 per cent of overall activity, and this occurred over a period of four years (see Figure 1 below).

\footnotetext{
4 Simon (2003) Figure 14 has capital values in Sydney rising an average 26 per cent per annum in the period 1985-89. His Figure 13 indicates a similar story in Melbourne and Perth markets for office property. Simon's source is Jones Lang Wooton, now Jones Lang LaSalle.

5 Simon (2003), Figure 14, shows the vacancy rate for Sydney, which had averaged about $2 \frac{1}{2}$ per cent in the period 1985-89, peaking at about 22 per cent in 1992-93. It took till 1997-98 for it to get down to just over 5 per cent.

6 ABS 5206.0 Table 2: Private non-residential construction expenditure measured in constant (chain volume measure) prices, seasonally adjusted series. Estimates exclude purchases of second-hand assets from the public sector. Estimates are for December quarter 2010 edition of ABS5206, downloaded 10 March 2011.
} 
Figure 1: Australian non-dwelling and dwelling construction

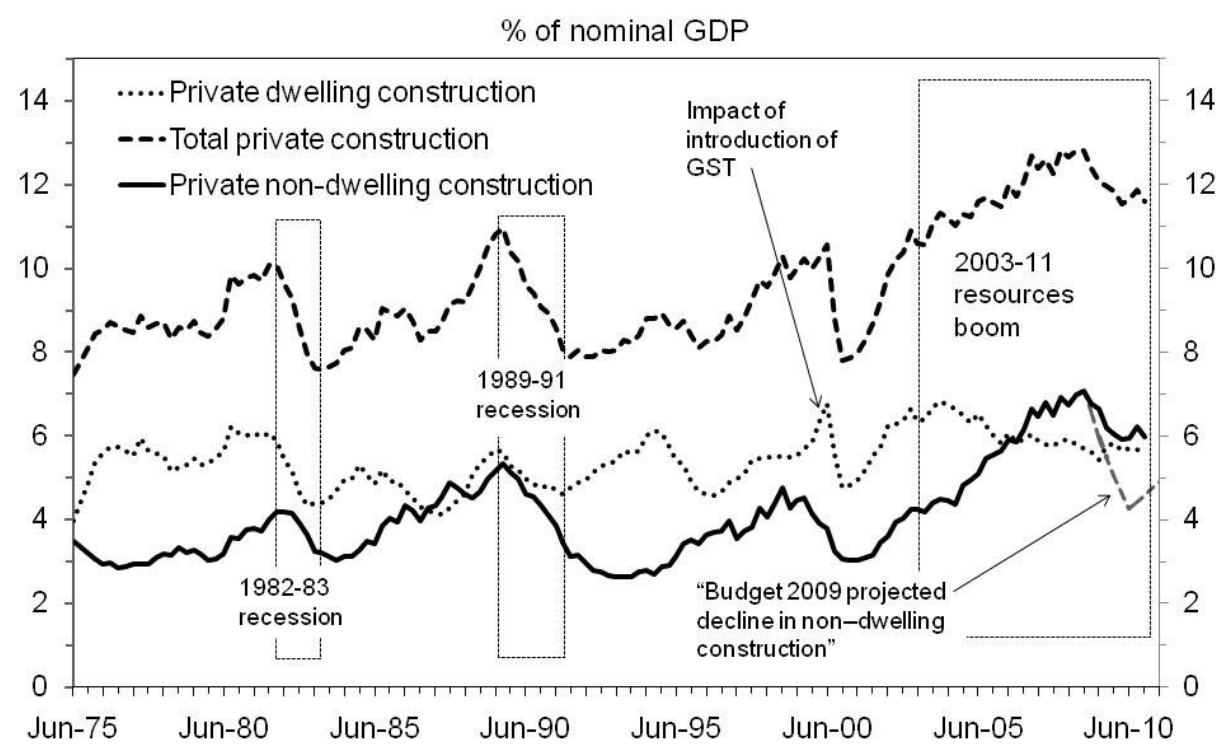

In the 1989-91 recession, the contraction in housing played a secondary role to that in commercial property. Capital-city median house prices experienced a sharp 59 per cent rise (30 per cent in real terms) in the three years to June quarter 1989. ${ }^{7}$ However, whereas commercial property prices declined 60 per cent in real terms, the median house price series for all capital cities did not fall in nominal terms, and fell only 8 per cent in real terms between their peak (in real terms) in March quarter 1989 and their trough in March quarter 1991, which does not rate this episode as a (price) bust. In activity terms, it was also mild. Given the sector's vulnerability to interest rates and swings in the economy, the peak (September quarter 1989) to trough (September quarter 1991) decline in private-dwelling capital expenditure of 13 per cent was relatively mild. If the cycles in its share of GDP (as shown in Figure 1) are taken into account, it was one of the milder cycles.

Bodman and Crosby (2005) argued that the 1989-91 recession was the product of monetary policy which was targeting a reduction in inflation and this version of history has found its way into some economic texts. This downplays the role of the asset price boom, which was not unique to Australia and, with different

7 Estimates for house prices for All Capital Cities. Real house prices derived by deflating by the implicit price deflator for Households Final Consumption Expenditure. House price data from ABS 6416.0 House Price Indexes: Eight Capital Cities, Table 1. Deflator from ABS 5206.0 Australian National Accounts: National Income, Expenditure and Product, Table 5. 
monetary policy settings, led to different outcomes and in some instances even more serious recessions than that experienced in Australia (Macfarlane 1992). The Reserve Bank concedes that, with hindsight, monetary policy might have been managed marginally differently. While the Reserve Bank was conscious at the time of the need to capitalise on the opportunity presented by economic weakness to return inflation to low levels, it was not ignoring the role of monetary policy in moderating the economic cycle. Fraser (1992), for example, concedes that maybe policy was eased too much in 1987 in response to the share market crash, and perhaps could have been eased faster in 1990 and 1991. They make the point that, at the time, the major criticism was that the Reserve Bank was reducing interest rates too fast.

Turning to fiscal policy, Fraser (1992) observes the reluctance to use fiscal policy more vigorously for counter-cyclical purposes in both the upswing and downswing in late 1980s/early 1990s. With regard to the balance between fiscal and monetary policy, he argued that this put too much of the burden on monetary policy. Consistent with that, Henry (2010) notes that, when a second successive quarter of negative GDP growth had confirmed Australia was in technical recession in late 1990, the Treasury advice was simply to allow the automatic fiscal stabilisers to work. A policy of using additional discretionary stimulus was not recommended. Later in February 1992, by which time the economy was growing again, the Government did introduce a fiscal stimulus package ('One Nation') which Henry observed had its principal impact in the mid-1990s, The corporate knowledge of Henry and other Treasury officers of the mistakes made in the early 1990s influenced his advice (as Head of Treasury 2001-11) in designing the fiscal policy response in 2008-09 (Henry 2010).

But whereas a fair degree of certainty was attached to a recession in the period 2008-10, by contrast the recession of 1989-91 caught policymakers off-guard. Watson (2002) writes that in the period 1987-90, neither the Treasury nor the Reserve Bank picked the direction of the economy; either the boom that followed the share market crash of 1987 or the 1989-91 recession (Watson: 80). Edwards (1996: 394) argues that as the recession unfolded the Treasury was still assuring the Government that there would be a 'soft landing'. More importantly, perhaps, the accounts by Watson and Edwards ${ }^{8}$ suggest that there was no consensus from the Treasury and Reserve Bank. If policymakers are required to be forward-looking, it helps if there is a clear consensus.

Fast forward to 2008. Were the pre-conditions there for a major recession? In the case of housing, prices had peaked in December quarter 2003, and then declined 3 per cent in the period to September quarter 2005 before rising to be 14 per

8 Edwards and Watson have inside accounts which can diverge from public statements. 
cent above their 2003 peak in June quarter 2008. ${ }^{9}$ The steady tightening in monetary policy in the period 2003-08 worked against the boost in demand for housing from the resources boom, including the related surge in net immigration. Housing activity was constrained in this period, with starts averaging close to 160,000 per annum in the five years to June quarter 2008, compared with National Housing Supply Council $(2010)^{10}$ estimates of underlying demand of upwards of 174,000 in this period. This saw the vacancy rate decline from about 4 per cent in 2003 to below 2 per cent in mid-2008 and this evidence of supply shortage was reflected in rents accelerating from near zero growth to growth of 4.8 per cent in real terms in the year to June quarter 2008, and 5.6 per cent in the year to June quarter 2009. ${ }^{11}$ This was in sharp contrast to the significant oversupply in housing, for example, in the US.

But, if we look at non-residential construction as a share of economic activity (Figure 1), the high level at which it was operating looked scarier than it did in 1989, when it was one of the pointers indicating the risk of recession. The difference in 2008 for Australia - and also compared with the US - was that the cause of the construction boom was not an asset bubble but an externally driven resources boom. The external forces were the sustained and rapid growth in demand from, amongst others, China and India, coming after a long period in which, in the case of iron ore, prices had been declining in real terms and world output had stagnated. ${ }^{12}$ After declining about 50 per cent in real terms in the period 1980-2000, prices have approximately trebled since then, inducing a significant lift in investment. The resources boom is naturally going to be vulnerable to a sharp downturn in demand from China and/or excess investment in new capacity. The Treasury expected this threat to materialise, with the 2009 Budget forecasting a sharp 26 per cent contraction in private non-residential construction in 2009/10 which would equate to a peak-to-trough decline of more than 30 per cent and was expected to return to its pre-boom share of GDP (Figure 1). ${ }^{13}$ Learning from that previous experience, a major component of the fiscal package, the BER building program, was targeted at the construction sector to modify the expected sharp contraction in activity in that sector. ${ }^{14}$

9 Estimates as for Footnote 7.

10 Figure 7.3 (p.132) in the National Housing Supply Council Report 2010 shows estimates of the gap between demand and supply in the period 2002-09.

11 Source for vacancy rates: Bloxham, Kent and Robson (2011) Figure 5, page 18.

12 In the period 1980-2000, the world output of iron ore rose just 4 per cent and US\$ prices stagnated in nominal terms, implying an approximate 50 per cent decline in prices. Source: ABARES (2010) ACS 2010 Iron Steel Tables 289, 293. US\$ prices deflated by Price Index for Personal Consumption Expenditure from US Bureau of Economic Analysis national Income and Product Accounts Table 1.1.4 downloaded 10 March 2011 from http://www.bea.gov/national/nipaweb/SelectTable.asp?Selected=N

13 Australian Government 2009a: 4. The comment refers to aggregate business investment returning to precommodity boom share of GDP but the forecasts in Table 1 indicate that the larger portion of this will occur via the 26 per cent contraction in non-dwelling construction investment. Refer Figure 1.

14 More specifically, it was targeted at commercial building as distinct from engineering construction (Australian Government 2009a: 25-7). 
In the event, the GFC proved to be more of an Atlantic than a global recession, and the likes of China and India quickly returned to normal growth, albeit with the help of some sizeable fiscal stimulus (Gruen 2010). The signal for that return of demand was commodity prices - base metals are a good bellwether and prices contracted sharply, to be 59 per cent below their average for the peak year of 2007 when prices troughed in February 2009. By April they had lifted 17 per cent from that trough and by December by 73 per cent. ${ }^{15}$ Prices were still 30 per cent below the 2007 peak year but 20 per cent above the 10-year average. Moreover, the key is the message given by the direction of prices, which rose another 15 per cent during 2010.

Consequently, the forecast contraction in construction did not materialise, as miners observed the better news built into the prices and took their finger off the pause button on some projects. Indeed, in historical terms, the contraction in construction (Figure 1) looks extremely modest by contrast with the early 1980s recession, the 1989-1991 recession and the downturn in the early 2000s. Activity contracted just 11 per cent from its December quarter 2008 peak to December quarter 2009 and had recovered about half of that decline by late 2010. ${ }^{16}$ Moreover, this decline was more than made up by the increase in publicsector demand. The upshot was that, with activity in housing also rising, that aggregate activity in 2010 was 8 per cent above 2008 levels (see Table 1). The problem here is that in 2008 the construction sector was operating at or beyond capacity.

Table 1: Real gross fixed-capital formation in construction (\$bn)

\begin{tabular}{llllll}
\hline & $\begin{array}{l}\text { Private non- } \\
\text { dwelling } \\
\text { construction }\end{array}$ & $\begin{array}{l}\text { Private } \\
\text { dwelling } \\
\text { construction }\end{array}$ & $\begin{array}{l}\text { Total Private } \\
\text { construction }\end{array}$ & $\begin{array}{l}\text { Public } \\
\text { construction }\end{array}$ & $\begin{array}{l}\text { Total Private } \\
\text { and Public }\end{array}$ \\
Mar-2008 & 20.5 & 18.2 & 38.7 & 8.3 & 47.1 \\
Jun-2008 & 20.3 & 18.5 & 38.9 & 7.8 & 46.7 \\
Sep-2008 & 21.7 & 18.5 & 40.2 & 8.5 & 48.7 \\
Dec-2008 & 22.2 & 18.0 & 40.2 & 8.9 & 49.1 \\
Mar-2009 & 21.5 & 17.6 & 39.1 & 9.3 & 48.4 \\
Jun-2009 & 21.2 & 16.8 & 37.9 & 9.5 & 47.4 \\
Sep-2009 & 19.7 & 17.8 & 37.5 & 10.7 & 48.2 \\
Dec-2009 & 19.6 & 18.1 & 37.7 & 10.9 & 48.7 \\
Mar-2010 & 19.7 & 17.9 & 37.5 & 12.5 & 50.0 \\
Jun-2010 & 20.4 & 18.6 & 39.0 & 12.9 & 51.9 \\
Sep-2010 & 21.3 & 18.6 & 39.9 & 12.6 & 52.5 \\
Dec-2010 & 20.7 & 18.5 & 39.2 & 12.6 & 51.8
\end{tabular}

Sources: ABS, 5206.0, Table 2: 'Expenditure on GDP', chain volume measure; ABS 8782.0, Table 1, 'Construction Work Done', chain volume measure

15 Reserve Bank of Australia Statistics Table G5: RBA Index of Commodity Prices. 
What lessons are we draw from this? One of the standard issues with using fiscal and monetary policy to manage the business cycle is the difficulty in forecasting the state of play when the lagged impact of policy changes impacts on activity. In 1989-91, failure to forecast the recession (resulting from excessive optimism of a soft landing) led to delay in the policy response. A related dilemma here is that governments are naturally reluctant to 'forecast recessions' because of the risk that this will contribute to the recession, but this makes it difficult to obtain a mandate for policy action. In 2008-09, we had the rare situation where recession seemed so inevitable that no effort was really required to secure such a mandate. In the event, the pessimism prevailing at the time proved overdone.

While it took some time to sink in, the GFC turned out to be an Atlantic recession which had only a short-term effect on the high-growth economies and commodity prices. From an Australian perspective, the GFC turned out to be a brief interruption to the resources boom which has been the dominant influence on the economy since 2003. The real policy challenge is managing a boom as Australia 'constructs' a much larger resources sector: at some point, supply will catch demand, prices will come down, and the resource-driven construction boom will end. The timing is not predictable (Stevens 2011a) and, given the long lead times in resource projects, mining companies inherently have difficulty in matching supply and demand. The risk then is a recession as the economy adjusts.

For Australia the GFC did not turn out to be quite the policy challenge expected, which was good. The real challenge for the period ahead is that the resources boom will come to an end. The high share of resources devoted to construction will at some point in the medium term suffer something like the reversal predicted in the 2009 Budget and that will occur at the same time that a reversal in the terms of trade produces a cyclical decline in the fiscal balance. In the interim, the question is whether both fiscal and monetary policy will play their part in moderating the boom and so make managing the end of the boom less painful, or whether a disproportionate weight will fall on monetary policy.

\section{References}

Australian Bureau of Agricultural and Resource Economics and Sciences (ABARES) 2010, Australian Commodities: December Quarter 2010, Australian Government, Canberra.

Australian Government 2009a, Budget Statement 2: Economic Outlook, Commonwealth of Australia, Canberra. 
Australian Government 2009b, Budget Statement 4: Assessing the Sustainability of the Budget, Commonwealth of Australia, Canberra.

Bernanke, B., Olekalns, N. and Frank, R. 2008, Principles of Macroeconomics, McGraw-Hill, Sydney.

Bloxham, P., Kent, C. and Robson, M. 2011, 'Asset Prices, Credit Growth, Monetary and Other Policies: An Australian Case Study', National Bureau of Economic Research, Working Paper 16845.

Bodman, P. and Crosby, M. 2005, 'When the US Sneezes, Do We Need to Catch a Cold? Historical and Future Linkages between the Australian and US Business Cycles' in C. Kent and D. Norman (eds.), Reserve Bank of Australia Economic Group Annual Conference: The Changing Nature of the Business Cycle, Reserve Bank of Australia, Sydney.

Chalk, N. A. 2002, 'Structural Balance and All That: Which Indicators to Use in Assessing Fiscal Policy', IMF Working Paper.

Congressional Budget Office 2008, 'The Outlook for Housing Starts 2009-12', US Government, Washington, 2008.

Edwards, J. 1996) Keating: The Inside Story, Penguin Books Australia, Melbourne.

Fraser, B. 1992, 'Two Perspectives on Monetary Policy', Reserve Bank of Australia Bulletin (September): 1-8.

Gruen, D. 2010, 'Forecasting in the Eye of the Storm', Paper presented at the Address to NSW Economic Society, Conference 4 June 2010, Sydney.

Gruen, D. and Stevens, G. 2000, 'Australian Macroeconomic Performance and Policy in the 1990s' in D. Gruen and S. Shrestha (eds), Reserve Bank of Australia Economic Group Annual Conference: The Australian Economy in the 1990s, Reserve Bank of Australia, Sydney.

Henry, K. 2009, 'Contemporary Challenges in Fiscal Policy', Paper presented at the Post-Budget Speech to The Australian Business Economists Conference, Sydney.

Henry, K. 2010, Talk to UNSW 'Meet the CEO', Sydney.

Macfarlane, I. 1989, 'Money, Credit and Demand for Debt', Reserve Bank of Australia Bulletin (May): 21-31.

Macfarlane, I. 1990, 'Credit and Debt: Part II', Reserve Bank of Australia Bulletin (May): 27-34. 
Macfarlane, I. 1992, 'Making Monetary Policy in an Uncertain World', Reserve Bank of Australia Bulletin (September): 9-14.

National Housing Supply Council 2010, '2nd State of Supply Report', Department of Families, Housing, Community Services and Indigenous Affairs, Australian Government, Canberra.

Simon, J. 2003, 'Three Australian Asset Price Bubbles', in A. Richards and B. Sith (eds) Reserve Bank of Australia Economic Group Annual Conference: Asset Prices and Monetary Policy, Reserve Bank of Australia, Sydney.

Stevens, G. 2011a, 'The Resources Boom', (23 February); available at: http:// www.rba.gov.au/speeches/2011/sp-gov-230211.html

Stevens, G. 2011b, 'The State of Things', (9 March); available at: http://www. rba.gov.au/speeches/2011/sp-gov-100311.html

Watson, D. 2002, Recollections of a Bleeding Heart: Paul Keating, PM, Random House Australia, Sydney. 